\title{
Correction to: Using soundscapes to assess biodiversity in Neotropical oil palm landscapes
}

\section{Paul R. Furumo $\mathbb{D}$ - T. Mitchell Aide $\mathbb{C}$}

Published online: 18 May 2019

(C) Springer Nature B.V. 2019

\section{Correction to: Landscape Ecol}

https://doi.org/10.1007/s10980-019-00815-w

In the original publication of the article the below given funding information was missed and now it is included in this correction:

The original article can be found online at https:// doi.org/10.1007/s10980-019-00815-w.

P. R. Furumo $(\square)$

Department of Environmental Sciences, University of Puerto Rico-Rio Piedras, PO Box 23360, San Juan 00931, Puerto Rico

e-mail: pfurumo@gmail.com

T. Mitchell Aide

Department of Biology, University of Puerto Rico-Rio

Piedras, PO Box 23360, San Juan 00931, Puerto Rico

e-mail: tmaide@yahoo.com
National Geographic Society, Rufford Foundation, and the Fulbright Program as funding sources for this research.

Publisher's Note Springer Nature remains neutral with regard to jurisdictional claims in published maps and institutional affiliations. 